\title{
Potency of Bacillus spp from Potato Rhizosphere as Active Ingredients for Biostimulant Formulation
}

\author{
Henry Kesaulya ${ }^{1}$, Hasinu Jeffij Virgowati ${ }^{1} \&$ Tuhumury Gratiana Normalita Celvia ${ }^{1}$ \\ ${ }^{1}$ Departement of Agroecotechnology, Agriculture Faculty of Pattimura University Ambon-Indonesia \\ Correspondence: Henry Kesaulya, Agriculture Faculty of Pattimura University. Jl. Ir. M. Putuhena Kampus \\ Poka-Ambon, Indonesia. E-mail: henry.unpat@gmail.com
}

Received: August 9, 2017

doi:10.5539/mas.v11n10p74

\author{
Accepted: September 11, $2017 \quad$ Online Published: September 27, 2017 \\ URL: https://doi.org/10.5539/mas.v11n10p74
}

\begin{abstract}
Bacteria that colonized plant roots can be identify, characterify and tested for their ability to stimulate plant growth. The purpose of this research is to know the ability of Bacillus spp bacteria as active ingredient of biostimulant formulation which aims to stimulate the growth of plants. Bacillus spp bacteria derived from rooting potato plants tested its ability to dissolve phosphate, $\mathrm{N}$ fixation, producing IAA, GA, siderophore and $\mathrm{HCN}$. The results showed different abilities in producing growth-promoting compounds from each tested strain. Bacillus niabensis Strain PT-32-1, Bacillus subtilis Strain SWI16b, Bacillus mojavensis Strain JCEN3, Bacillus subtilis Strain HPC21, Bacillus cereus Strain HY, and Bacillus moyavensis UCMB 5075 can be utilized as an active ingredient formulation biostimulant plant growth promoting non pathogenic.
\end{abstract}

Keywords: Bacillus spp, Biostimulant, Formulation, Non pathogenic, Potato

\section{Introduction}

Biostimulant products from bacterial active formulations are now widely used in agriculture with the aim of stimulant plant growth. Mode of action of biostimulant through different mechanisms with fertilizers, in which the mechanism of biostimulant activitate has so far been difficult to identify, due to the complexity of its bioactive compounds, so it must be proven through physiological and biological studies (Bulgari et al., 2015; Sharma et al., 2016). Biostimulant is not a nutrient or pesticide, but positively affected plant growth and health as well environmental friendly. Biostimulant contains bioactive compounds or microorganisms that can be applied to plants in order to improve the efficiency of nutrient absorption, tolerance of biotic, abiotic stress and can improve the quality of plants (Calvo et al., 2014; du Jardin, 2015; Halpern et al., 2015). Plant growth stimulate throughout the life cycle from seed germination, increased yield induction and plant quality including increased: plant metabolism, resistance mechanisms against abiotic and biotic stress (Kauffman et al. 2007; Keunen et al., 2013; Kumari and Sairam, 2013; Wang et al., 2013; Wasternack and Hause, 2013; Zeng et al., 2014; Calvo et al., 2014), improved assimilation of nutrients and translocation, product quality, including sugar content, water efficiency used, and Soil fertility (Banks and Percival, 2012).

Bacteria are the most abundant microorganisms in the rhizosphere, most likely to affect plant physiology, especially through plant rooting colonization (Kloepper, 2007). Rhizospheric bacteria that colonized rooting play an important role in the regulation of plant growth triggers known as plant growth promoting rhizosphere (PGPR) (Kloepper et al, 1980). Various species of bacteria such as Pseudomonas, Azospirillum, Azotobacter, Klebsiella, Enterobacter, Alcaligenes, Arthrobacter, Burkholderia, Bacillus and Serratia are reported to increase plant growth (Kloepper et al., 1989; Glick, 1995).

The bacteria that colonized the rhizosphere can be identify and characterify according to their morphology and physiological influences on plants and the way bacteria interact with roots. A number of PGPR have been identified as important roles, especially their role as a promoting of plant growth (Kloepper et al, 1989; Glick, 1995; Kauffman et al. 2007; Keunen et al., 2013; Kumari and Sairam, 2013; Wang et al., 2013; Wasternack and Hause, 2013; Zeng et al., 2014; Banks and Percival, 2012). The purpose of this research is to know the ability of Bacillus spp from root potato in producing biostimulant compound of plant growth. 


\section{Method}

\subsection{Source of Bacteria}

The bacteria tested for the production ability of the biostimulant compound are: Bacillus niabensis Strain PT-32-1, Bacillus niabensis, Bacillus subtilis Strain SWI16b, Bacillus subtilis Strain Strain HPC21, Bacillus cereus Strain HY, Bacillus moyavensis JCEN3, Bacillus moyavensis UCMB 5075 and Bacillus spp derived from potato rizosphere (Solanum tuberosum L.) var. Hartapel. The bacteria were cultured on NA medium and then tested the potential for production of biostimulant compounds including the ability to solve phosphate, $\mathrm{N}$ fixation, production of ACC-deaminase, hormone, siderophore, and HCN.

\subsection{Phosphate Solubilization Test}

Phosphate solubilization was tested by using to the Pikovskaya method (Sundara and Shinha, 1962; Subba Rao, 1982). Measurement of solubilization phosphate concentration by using liquid Phikovkaya media. Absorbance was measured on a $693 \mathrm{~nm}$ UV-VIS spectrophotometer. Standard $\mathrm{PO}_{4}$ curve (titrisol) is made from dilution with concentration with regression equation $\mathrm{Y}=0.191 \mathrm{x}+0.048$ where $\mathrm{R} 2=0.957$.

\subsection{Free Nitrogen Fixation}

The ability of bacterial isolates to bind free nitrogen was tested using Burk N-free medium (Stella and Suhaimi, 2010). Bacteria capable of growing on N-free Burk media are indicated as bacteria capable of fixing nitrogen.

\subsection{Production of ACC-deaminase}

Testing of the ability of ACC-deaminase enzyme-producing bacteria was performed by culturing bacterial isolates on Dworkin-Foster's minimum saline medium (DF) (Dworkin and Foster, 1958) enriched with 1-aminocyclopropane-1-carboxylate (ACC) as the only source of nitrogen (Glick, 1995). Bacterial capable of growing on this medium are indicated as ACC-deaminase-producing bacteria.

\subsection{Production of Indole Acetic Acid (IAA)}

The production of indole-3-acetic acid (IAA) auksin was tested using nutrient broth medium (NB) and Salkowski reagent (Gutierrez et al, 2009; Glickman and Dessaux, 1995). Pink color changes show IAA production. The concentration of auxin was measured using standard IAA curve with regression equation $\mathrm{Y}=$ $0.064 \mathrm{x}+0.09$ where $\mathrm{R} 2=0.995$, made from serial dilution of IAA stock solution, absorbance was measured at $535 \mathrm{~nm}$ at UV-VIS spectrophotometer.

\subsection{Production of Gibberellic Acid (GA3)}

The production of gibberellic acid was tested according to standard methods (Borrow at al, 1995). The absorbent was measured at $254 \mathrm{~nm}$ on the UV-VIS spectrophotometer. GA3 concentration was measured using standard GA3 curve with regression equation $\mathrm{Y}=0.888 \mathrm{x}+0.441$ where $\mathrm{R} 2=0.921$, made from serial dilution of GA3 stock solution.

\subsection{Siderophore Production Test}

The production of bacterial isolate siderefors was tested using method described by Sivasakthivelan and Stella (2012). The bacterial isolates were incubated at $37^{\circ} \mathrm{C}$ for 7 days. Absorbance was determined at $560 \mathrm{~nm}$ with sodium salicylate as the standard for salicylate estimation. Standard sodium salicylate is made from dilution with a concentration of salicylic nantrium with regression equation $\mathrm{Y}=0.179 \mathrm{x}+0.027$ where $\mathrm{R} 2=0.902$. Measurement of catechol type siderophores in absorbance of $700 \mathrm{~nm}$ with 2,3 dihydroxy benzoate acid (DHBA) as standard with regression equation $\mathrm{Y}=0.209 \mathrm{x}+0.038$ where $\mathrm{R} 2=0.955$.

\subsection{HCN Test}

Screening of bacterial isolates that produce hydrogen cyanide is carried out according to the method described by Bakker and Schippers (1987). Cyanide production was detected using a solution of cyanide detection solution. Changes in light brown to dark brown show the production of HCN.

\subsection{Hypersenstivity Test}

The bacterial suspension was injected $1 \mathrm{ml}(106 \mathrm{CFU} / \mathrm{ml}$ with $\mathrm{OD}=0.06$ measured at $660 \mathrm{~nm}$ spectrophotometer absorption) in the tobacco leaf tobacco intervention area (Lelliot and Stead, 1987). In this test distilled water was used as a negative control and suspension of Ralstonia solanacearum bacteria as a positive control. The hypersensitivity reaction was observed after 12.24 and 72 hours of injection. Positive hypersensitive reaction response is shown in the presence of brown necrosis spots and dryness in leaf tissue or vice versa when shown negative hypersensitive reaction is not seen any changes in the leaf surface in the form of brown spots as a form 
of necrosis.

\section{Results and Discussion}

The ability of Bacillus spp in the phosphate solubilization process, $\mathrm{N}$ fixation, results in ACC-deaminase, hormone production (IAA and GA3), production of siderophores, HCN and hypersensitivity reactions are presented in Table 1.

Table 1. Bacillus spp ability as Plant Growth Promoting Rhizobacteria

\begin{tabular}{|c|c|c|c|c|c|c|c|c|}
\hline \multirow[t]{2}{*}{ Bacteria } & \multirow{2}{*}{$\begin{array}{l}\text { Phosphate } \\
\text { solubilization } \\
\left(\mathrm{mg} \mathrm{l}^{-1}\right)\end{array}$} & \multirow[t]{2}{*}{$\begin{array}{l}\text { Fixation } \\
\text { of } \mathrm{N}\end{array}$} & \multirow{2}{*}{$\begin{array}{l}\text { Production of } \\
\text { ACC-deaminase }\end{array}$} & \multicolumn{2}{|c|}{$\begin{array}{l}\text { Production of } \\
\text { Hormon } \\
\left(\mathrm{mg} \mathrm{l}^{-1}\right)\end{array}$} & \multicolumn{2}{|c|}{$\begin{array}{l}\text { Production of } \\
\text { Siderophores }\end{array}$} & \multirow{2}{*}{$\begin{array}{l}\text { Production } \\
\text { of } \\
\mathrm{HCN}\end{array}$} \\
\hline & & & & IAA & $\mathrm{GA}_{3}$ & $\begin{array}{l}\text { Chatecol } \\
\left(\mathrm{mg} \mathrm{l}^{-1}\right)\end{array}$ & $\begin{array}{l}\text { Salisilat } \\
\left(\mathrm{mg} \mathrm{l}^{-1}\right)\end{array}$ & \\
\hline $\begin{array}{l}\text { Bacillus niabensis } \\
\text { Strain PT-32-1 }\end{array}$ & 14.237 & + & + & 5.114 & 2.866 & 2.257 & 3.228 & + \\
\hline Bacillus niabensis & - & + & + & 3.173 & 5.140 & 0.685 & 3.055 & + \\
\hline $\begin{array}{l}\text { Bacillus subtilis Strain } \\
\text { SWI16b }\end{array}$ & 12.492 & + & + & 5.816 & 6.389 & 1.709 & 3.347 & + \\
\hline $\begin{array}{l}\text { Bacillus subtilis Strain } \\
\text { HPC } 21\end{array}$ & 12.302 & + & + & 0.329 & 4.217 & 3.025 & 2.772 & - \\
\hline $\begin{array}{l}\text { Bacillus cereus Strain } \\
\text { HY }\end{array}$ & - & + & + & 1.121 & 4.854 & 1.568 & 3.284 & - \\
\hline $\begin{array}{l}\text { Bacillus moyavensis } \\
\text { Strain JCEN3 }\end{array}$ & 13.210 & + & + & 0.393 & 5.784 & 4.206 & 4.121 & - \\
\hline $\begin{array}{l}\text { Bacillus moyavensis } \\
\text { Strain UCMB } 5075\end{array}$ & - & + & + & 1.501 & 4.786 & 5.297 & 4.245 & - \\
\hline Bacillus spp. & - & - & - & 0.574 & 5.880 & 4.206 & 4.121 & - \\
\hline
\end{tabular}

Note: $(+)$ positively produces ACC deaminase, $\mathrm{N}$-fixation and $\mathrm{HCN}$ production (-) producing negative ACC deaminase, solubilization phosphate, $\mathrm{N}$-fixation and production of $\mathrm{HCN}$.

The ability of phosphate solubilization of bacteria was characterized by the formation of a halozone around bacteria on Phikovskaya media (Fig. 1a). The formation of clear zone is a process of degradation of tricalcium phosphate in Phikovskaya media as a form of bacterial ability to dissolve phosphate. From eight bacterial strains tested there were only four bacterial isolates showing the ability to dissolve phosphates: Bacillus niabensis Strain PT-32-1, Bacillus subtilis Strain SWI16b, Bacillus mojavensis Strain JCEN3 and Bacillus subtilis Strain HPC21 with different levels of phosphate dissolution (Table 1 ).

The ability of bacteria growing on Dworkin-Foster selective medium are indicated as bacteria that have the ability to use ammonium sulfate as a bacterial constitutive ability to produce ACC-deaminase. Selected bacteria in Dworkin-Foster medium are able to use ACC substrate as the only nitrogen source and have the ability to produce ACC-deaminase. The ACC-deaminase enzyme is present in many rhizosphere bacteria, where bacteria take ACC secreted by the roots and convert it to $\alpha$-ketobutyrate and ammonia (Glick et al., 2007). In Table 1 showed that bacteria showing ACC-deaminase activity also indicate $\mathrm{N}$ fixation activity. This showed that there is a relationship between $\mathrm{N}$ fixation activity and ACC-deaminase activity. Based on several studies of bacteria capable of growing on Burk N-free media indicated that bacteria capable of fixing nitrogen (Ding at al, 2005; Döbereiner and Pedrosa, 1987; Döbereiner et al. 1995, Mantilla-Paredes et al. 2009, Sgroy et al, 2009 Silva dan Melloni, 2011) can form the pellicle (Lea-Madi et al. 1988; da Silva et al., 2013), can produce ammonium (Shanmugam and Valentine, 1975; Saribay, 2003) and have nitrogenase activity (da Silva et al, 2013; Dilworth, 1966; Ueda et al. 1995; Ohkuma et al. 1996; Widmer et al. 1999; Kirshtein et al. 1991; Garbeva et al. 2001; Sessitsch et al. 2005; Reiter et al. ; Chelius and Triplett, 2001).

The ability to produce IAA varies from each strain of Bacillus (Table 1). The difference in IAA concentrations produced by the various bacteria tested was due to differences in bacterial capabilities utilizing tryptophan. The concentration of IAA produced by bacteria depends on the substrate of L-tryptophan in the medium, which is detected by pink change after the addition of Salkowski reagent in the test process (Figure 1b).

All of the tested Bacillus strains have the ability to produce gibberellic acid (GA3). Levels of concentration 
gibberellic acid are presented in Table 1. It is estimated that bacteria can increase GA levels in bacterial cultures due to GAs production, deconjugating GAs from root exudates or inactive GA hydroxylating (Bottini et al., 2004).

The number of bacterial isolates capable of secreting siderophores were the same as the number of bacterial isolates capable of producing ACC-deaminase, IAA, GA and N fixing in all tested Bacillus strains. Siderophore microbials can be biocontrol for plants because of their competitive effects with pathogens (Hofte, 1993). Production of siderophores with maximum or minimum concentration is not found in the same strain of bacteria but in different bacterial strains. These findings were showed in Pseudomonas fluorescens, where the maximum and minimum siderophore concentrations produced found on the same bacterial isolate (Saranraj, et al., 2013; Sivasakthivelan and Stella 2012.) The difference was predicted cause by differences in synthesis capability of both types Siderophore from bacterial isolate Bacillus spp. Based on the results of the study, Bacillus niabensis Strain PT-32-1, Bacillus niabensis and Bacillus subtilis Strain SWI16b positively produce hydrogen cyanide characterized by color change on cyanide detection solution indicator paper to brown (Figure 1c). Hydrogen cyanide produced by many rhizobacteria has been postulated to play a role in the biological control of pathogens (Defago et al., 1990), and is said to be an inducer of plant resistance and growth trigger (Schippers, 1993).

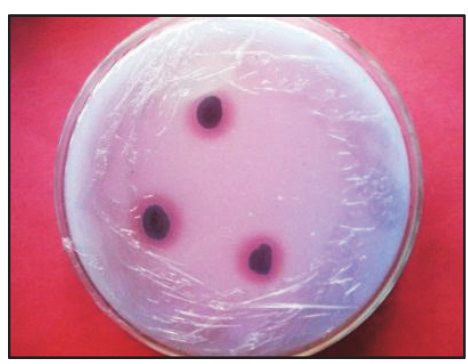

(a)

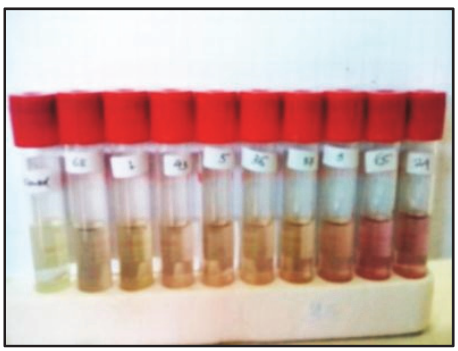

(b)

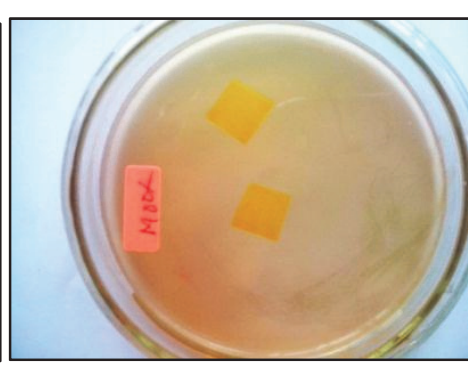

(c)

Figure 1. (a) Hallozone phosphate on solubilization test, (b) Color change of Bacteria suspension on IAA test, (c) result of $\mathrm{HCN}$ test

Hypersensitivity test results showed that all bacteria did not trigger hypersensitive reactions in tobacco leaves (Table 2). Suspension of bacteria injected in tobacco plants was not pathogenic to plants. This reaction was only found in bacterial isolates Ralstonia $s p$. as a positive control. The

neocrotic symphtoms was only shown by Ralstonia sp treatment as a positive control. Klement et al., (1990) suggests that at this stage there was a reaction between phenol compounds contained in the vacuole with subsation present in the cytoplasm and formed cytololic compound resulting necrosis symptoms.

Table 2. Hypersensitivity Response Bacterial Isolates in Tobacco Leaves

\begin{tabular}{lllll}
\hline \multirow{2}{*}{ Bacteria } & \multicolumn{4}{l}{ Hipersensitive Reactions } \\
\cline { 2 - 5 } & 12 hours & 24 hours & 48 hours & 72 hours \\
\hline Bacillus niabensis Strain PT-32-1 & - & - & - & - \\
Bacillus niabensis & - & - & - & - \\
Bacillus subtilis Strain SWI16b & - & - & - & - \\
Bacillus subtilis Strain HPC21 & - & - & - & - \\
Bacillus cereus Strain HY & - & - & - & - \\
Bacillus mojavensis Strain JCEN3 & - & - & - & - \\
Bacillus moyavensis UCMB 5075 & - & - & - & - \\
Bacillus spp & - & - & - & - \\
Akuades steril & - & - & - & - \\
Ralstonia solanasearum & + & + & + & + \\
\hline
\end{tabular}

Note: + positive shows hypersensitivity reaction, no hypersensitivity reactions occur.

\section{Conclusion}

Bacillus niabensis Strains of PT-32-1, Bacillus subtilis Strain SWI16b, Bacillus mojavensis Strain JCEN3, 
Bacillus subtilis Strain HPC21, and Bacillus moyavensis UCMB 5075 have potential as biostimulant active ingredients of plant growth because physiological characters capable of solubilization phosphate, nitrogen fixition, producing ACC-deaminase, IAA, GA, and siderophores as well as non hypersensitive.

\section{References}

Bakker, A. W., \& Schippers, B. (1987). Microbial cyanide production in the rhizosphere to potato yield reduction and Pseudomonas spp. mediated plant growth stimulation. Soil Biology and Biochemistry, 19, 451-457.

Banks, J. M., \& Percival, G. C. (2012). Evaluation of Biostimulants to Control Guignardia Leaf Blotch (Guignardia aesculi) of Horsechestnut and Black Spot (Diplocarpon rosae) of Roses. Arboriculture and Urban Forestry, 38(6), 258-261.

Borrow, A., Brain, P. W., Chester, U. E., Curtis, P. J., Hemming, H. G., Jeffereys, E. C., Lloyd, R. B., Nixon, I. S., Norris, G. L. F., \& Radley, N. (1995). Gibberellic acids a metabolic product of the fungus Gibberella fujikuroi some observations on its production and isolation. J. Sci. Food. Agric., 6, 340-348.

Bottini, R., Cassan, F., \& Piccoli, P. (2004). Giberellin production by bacteria and its involvement in plant growth promotion and yield increase. Appl. Microbiol. Biotechnol, 65, 497-503.

Bulgari, R., Cocetta, G., Trivellini, A., Vernieri, P., \& Ferrante, A. (2015). Biostimulants and crop responses: A review. Biol. Agric. Hortic, 31(1), 1-17.

Calvo, P., Nelson, L., \& Kloepper, J. W. (2014). Agricultural uses of plant biostimulants.Plant Soil 383, 3-41.

Chelius, M. K., \& Triplett, E. W. (2001). The diversity of archaea and bacteria in association with the roots of Zea mays L. Microb. Ecol., 41, 252-263.

da Silva, K., Rafaela, S. A. N., Adriana, S. L., Alexandre, B., \& Fatima, M. de S. M. (2013). Density and diversity of diazotrophic bacteria isolated from Amazonian soils using N-free semi-solid mediaSci. Agric. (Piracicaba, Braz.), 68(5), 518-525

Defago, G., Berling, C. H., Burger, U., Haas, D., Kahr, G., Keel, C., Voisard, C., Wirthner, P., \& Wuthrich, B. (1990). Suppression of black root rot of tobacco and other root diseases by strains of Pseudomonas fluorescens potential applications and mechanisms. In: Biological control of soil bore plant pathogens, D. Hornby (Ed.). CAB International, Walligfort, Oxon, U.K. pp.93-98.

Dilworth, M. J. (1966). Acetylene reduction by nitrogen fixing preparations from Clostridium pasteurianum. Biochem. Biophys, Acta, 127, 285-294.

Ding, Y., Wang, J., Liu, Y., \& Chen, S. (2005). Isolation and identification of nitrogen-fixing bacilli from plant rhizospheres in Beijing region. Journal of Applied Microbiology, 99, 1271-1281

Döbereiner, J., \& Pedrosa, F. O. (1987). The genus Azospirillum. In: Nitrogen-fixing bacteria in non-leguminous crop plants. Madison: Science Tech. Publishers, p.155.

Döbereiner, J., Baldani, V. L. D., \& Reis, V. M. L. (995). Endophytic occurrence of diazotrophic bacteria in non-leguminous crops. In: Fendrik I, del Gallo M, Vanderleyden J, de Zamaroczy M (eds) Azospirillum VI and related microorganisms. Berlin, Heidelberg: Springer-Verlag, 15-30.

du Jardin, (2015). Plant biostimulants: Definition, concept, main categories and regulation. Scientia Horticulturae, 196, 3-14.

Dworkin, M., \& Foster, J. (1958). Experiments with some microorganisms which utilize ethane and hydrogen. J. Bacteriol., 75, 592-601. PMID: 13538930

Garbeva, P., van Overbeek, L. S., van Vuurde, J. W. L., \& van Elsas, J. D. (2001). Analysis of endophytic bacterial communities of potato by plating and denaturating gradient gel electrophoresis (DGGE) of $16 \mathrm{~S}$ rDNA based PCR fragments. Microb. Ecol, 41, 369-383.

Glick, B. R. (1995). The enhancement of plant growth by free living bacteria. Canadian Journal of Microbiology, 41(Suppl 2), 109-114.

Glick, B. R., Cheng, Z., Czarny, J., \& Duan, J. (2007). Promotion of plant growth by ACC-deaminase-producing soil bacteria. Eur. J. Plant Pathol, 119, 329-339.

Glickman, E., \& Dessaux, Y. (1995). A critical examination of the specificaty of the Salkowski reagent for indolic compoumds produced by phytopatogenic bacteria. Appl Environ Microbial, 61, 793-796.

Gutierrez, C. K., Matsui, G. Y., Lincoln, D. E., \& Lovel, C. R. (2009). Production of the phytohormone 
indole-3acetic acid by the estuarine species of the genus Vibrio. Appl Environ Microbiol, 75, 2253-2258.

Halpern, M., Bar-Tal, A., Ofek, M., Minz, D., Muller, T., \& Yermiyahu, U. (2015). The use of biostimulants for enhancing nutrient uptake. In: Sparks, D.L. (Ed.). Advancesin Agronomy, 129, 141-174.

Hofte, M. (1993). Classes of microbial siderophore. In: Barton LL, Hemming BC (eds) Iron chelation in plants and soil microorganisms. Academic Press, San Diego, 3-26.

Kauffman, G. L., Kneivel, D. P., \& Watschke, T. L. (2007). Effects of a biostimulant on the heat tolerance associated with photosynthetic capacity, membrane thermostability, and polyphenol production of perennial ryegrass. Crop Sci., 47, 261-267.

Keunen, E., Peshev, D., Vangronsveld, J., Van, den E. W., \& Cuypers, A. (2013). Plant sugars are crucial players in the oxidative challenge during abiotic stress: extending the traditional concept. Plant Cell Environ, 36, $1242-1255$.

Kirshtein, J. D., Pearl, H. W., \& Zehr, J. P. (1991). Amplification, cloning, and sequencing of a nifh segment from aquatic microorganisms and natural communities. Appl. Environ. Microbiol, 57, 2645-2650.

Klement, Z., Rudolph, K., \& Sands, D. C. (1990). Methods in Phytobacteriology, Akademiai Kiado, Budapest.

Kloepper, J. W., Gutierrez-Estrada, A., \& McInroy, J. A. (2007). Photoperiod regulates elicitation of growth promotion but not induced resistance by plant growth-promoting rhizobacteria. Can. J. Microbiol, 53, 159167.

Kloepper, J. W., Lifshitz, R., \& Zablotowicz, R. M. (1989). Free-living bacterial inocula for enhancing crop productivity. Trends in Biotechnology, 7(Suppl 2), 39-43.

Kloepper, J. W., Scrhoth, M. N., \& Miller, T. D. (1980). Effects of rhizosphere colonization by plant growth promoting Rhizobacteria on potato plant development and yield. Journal of Phytopathology, 70(Suppl 11), 1078-1082.

Kumari, A., \& Sairam, R. K. (2013). Moisture stress induced increases in the activity of enzymes of osmolytes biosynthesis are associated with stress tolerance in wheat genotypes. Indian J Plant Physiol, 18, 223-230.

Lea-Madi, M., Kessel, E. S., \& Henis, Y. (1988). Electron microscopic studies of aggregation and pellicle formation in Azospirillum spp. Plant and Soil, 109, 115-121.

Lelliott, R. A., \& Stead, D. E. (1987). Methods for the diagnosis of bacterial diseases of plants. In: Preece TF, ed. Methods in Plant Pathology, vol 2. Oxford, UK: Blackwell Scientific Publications, 44-56.

Mantilla-Paredes, A. J., Cardona, G. I., Peña-Venegas, C. P., Murcia, U., Rodríguez, M., \& Zambrano, M. M. (2009). Distribuición de bacterias potencialmente fijadoras de nitrógeno y su relación con parámetros fisicoquímicos con tres coberturas vegetales en el sur de la Amazonia colombiana. Rev. Biol. Trop, 57, 915-927.

Ohkuma, M., Noda, S., Usami, R., Horikoshi, K., \& Kudo, T. (1996). Diversity of nitrogen fixation genes in the symbiotic intestinal microflora of the termite Reticulitermes speratus. Appl. Environ. Microbiol, 62, 2747 2752.

Reiter, B., Pfeifer, U., Schwab, H., \& Sessitsch, A. (2002). Response of endophytic bacterial communities in potato plants to infection with Erwinia carotovora subsp. atrospetica. Appl. Environ. Microbiol, 68, 22612268.

Saranraj, P., Sivasakthivelan, P., \& Sakthi, S. S. (2013). Prevalence and production of plant growth promoting substance by Pseudomonas fluorescens isolated from paddy rhizosphere soil of Cuddalore district, Tamil Nadu, India. African Journal of Basic and Applied Sciences, 5(2), 95 - 101.

Schippers B. (1993). Exploitation of microbial mechanisms to promote plant health and plant growth. Phytoparasitica, 21, 275-279

Sessitsch, A., Reiter, B., Pfeifer, U., \& Wilhelm, E. (2005). Cultivation-independent population analysis of bacterial endophytes in three potato varieties based on eubacterial and Actinomycetesspecific PCR of $16 \mathrm{~S}$ rRNA genes. FEMS Microbiol. Ecol, 39, 23-32.

Sgroy, V., Cassa' n, F., Masciarelli, O., Del Papa, M. F., Lagares, A. \& Luna, V. (2009). Isolation and characterization of endophytic plant growth-promoting (PGPB) or stress homeostasis-regulating (PSHB) bacteria associated to the halophyte Prosopis strombulifera. Appl Microbiol Biotechnol, 85, 371-381.

Sharma, H. S. S., Selby., C., Carmichael., E., McRoberts., C., Rao., J. R., Ambrosino, P., Chiurazzi, M., Pucci, 
M., \& Martin, T. (2016). Physicochemical analyses of plant biostimulant formulations and characterization of commercial products by instrumental techniques. Chem. Biol. Technol. Agric., 3, 13.

Silva, T. F., \& Melloni, R. (2011). Densidade e diversidade fenotípica de bactérias diazotróficas não simbióticas em solos da Reserva Biológica Serra dos Toledos, Itajubá (MG). Rev. Bras. Ci. Solo, 35, 359-371.

Sivasakthivelan, P., \& Stella, D. (2012). Studies on the Phytohormone Producing Potential of Agriculturally Beneficial Microbial (ABM) Isolates from Different Rhizosphere Soils of Sunflower in Tamil Nadu. International Journal of Pharmaceutical \& Biological Archives, 3(5), 1150-1156

Stella.M., \& Suhaimi. M. (2010). Selection of suitable growth medium for free-living diazotrophs isolated from compost. J. Trop. Agric. and Fd. Sci., 38(2), 211-219

Subba, R. N. S. (1982). Biofertilizer in Agriculture. Oxford and IBH Publish co. New Delhi. Bombai.

Sundara, R. W. C. B., \& Shinha, M. K. (1962). Phosphate dissolving microorganism in the soil and rizophere. Indian J. Sci., 23, 272-278.

Ueda, T., Suga, Y., Yahiro, N., \& Matsuguchi, T. (1995). Remarkable N2-fixing bacterial diversity detected in rice roots by molecular evolutionary analysis of $n$ if $H$ gene sequences. J. Bacteriol., 177, 1414-1417.

Wang, M., Zheng, Q., Shen, Q., \& Guo, S. (2013). The critical role of potassium in plant stress response. Int. J. Mol Sci., 14, 7370-7390.

Wasternack, C., \& Hause, B. (2013). Jasmonates: biosynthesis, perception, signal transduction and action in plant stress response, growth and development. An update to the 2007 review in Annals of Botany. Ann Bot., $111,1021-1058$.

Widmer, F., Schaffer, B. T., Porteous, L. A., \& Seidler, R. J. (1999). Analysis of nifh gene pool complexity in soil and litter at a Douglas fir forest site in Oregon Cascade Mountain Range. Appl. Environ. Microbiol, 65, 374-380.

Zeng, H., Wang, G., Hu, X., Wang, H., Du, L., \& Zhu, Y. (2014). Role of microRNAs in plant responses to nutrient stress. Plant Soil, 374, 1005-1021.

\section{Copyrights}

Copyright for this article is retained by the author(s), with first publication rights granted to the journal.

This is an open-access article distributed under the terms and conditions of the Creative Commons Attribution license (http://creativecommons.org/licenses/by/4.0/). 